Canadian University Music Review

Canadian University Music Review

Revue de musique des universités canadiennes

George J. Buelow. Thorough-Bass Accompaniment according to

Johann David Heinichen. Revised edition. Lincoln, Neb., and

London: University of Nebraska Press, 1992. xvii, 462 pp. ISBN

0-8032-6106-3 (рa)

\title{
Sandra Mangsen
}

Numéro 14, 1994

URI : https://id.erudit.org/iderudit/1014319ar

DOI : https://doi.org/10.7202/1014319ar

Aller au sommaire du numéro

Éditeur(s)

Canadian University Music Society / Société de musique des universités

canadiennes

ISSN

0710-0353 (imprimé)

2291-2436 (numérique)

Découvrir la revue

Citer ce compte rendu

Mangsen, S. (1994). Compte rendu de [George J. Buelow. Thorough-Bass Accompaniment according to Johann David Heinichen. Revised edition. Lincoln, Neb., and London: University of Nebraska Press, 1992. xvii, 462 pp. ISBN 0-8032-6106-3 (pa)]. Canadian University Music Review / Revue de musique des universités canadiennes, (14), 210-215. https://doi.org/10.7202/1014319ar

All Rights Reserved ( C Canadian University Music Society / Société de musique des universités canadiennes, 1994
Ce document est protégé par la loi sur le droit d'auteur. L’utilisation des services d'Érudit (y compris la reproduction) est assujettie à sa politique d'utilisation que vous pouvez consulter en ligne.

https://apropos.erudit.org/fr/usagers/politique-dutilisation/ 
Should it not be, rather, a tool in the service of a more inclusive phenomenon, a device subservient to the multifarious experience of our art? We theorists must be reminded, once in a while, that affirming tonality is NOT the goal and purpose of tonal music. In spite of its undeniable importance, tonality is but one of a set of tightly intertwined means put in the service of expressive ends. This issue, unfortunately, seldom surfaces. Very late in the book, Dahlhaus hints at what could be a suitable frame of reference for assessing harmonic and tonal features:

A harmonic analysis that neglects the other features of compositional technique would be incomplete even as an analysis of harmony. Many features of harmony stand out more clearly or only become recognizable at all when one studies the reciprocal relationships by which harmony is bound up with a composition's rhythm and form. (p. 297)

Upon reading the last page of this superb book, the reader may be left with the impression of having come full circle, but this circle ends at a much higher altitude than it started. Along the way, some stones may have been left unturned or turned the wrong way around. But these can easily be forgotten at the sight of the panorama unfolding before the mind's eye. Dahlhaus's guidance in scaling these heights must be acknowledged and Robert $O$. Gjerdingen is to be praised most heartily for making this monumental contribution accessible to the Englishspeaking public.

Paul Cadrin

George J. Buelow. Thorough-Bass Accompaniment according to Johann David Heinichen. Revised edition. Lincoln, Neb., and London: University of Nebraska Press, 1992. xvii, 462pp. ISBN 0-8032-6106-3 (pa)

In this volume and elsewhere, George J. Buelow has contributed a great deal to our understanding of German baroque theory and practice; he has been particularly interested in well-defined and focused studies of performance practice: "We need fewer publications on the thorough-bass that attempt to describe the practice for its entire two-hundred-year duration and more that concentrate on individual periods, countries, and generational solidifications of style". ${ }^{1}$ I could not agree more. His summary of and commentary on the ideas of Johann David

1 George J. Buelow, review of Figured Bass Accompaniment by Peter Williams, The Musical Quarterly 58 (1972): 313. 
Heinichen has been available, in one form or another, for over thirty years; the latest, revised edition has only recently appeared in the paperback format reviewed here. ${ }^{2}$ It was a pioneering effort only recently supplemented by translations of treatises by Delair and St. Lambert and volumes devoted to Handel's continuo practice. ${ }^{3}$ Reviewers of the first edition praised Buelow for his extraordinarily helpful and succinct presentation of the essence of Heinichen's ideas on figured bass realization, which originally occupied nearly 1000 pages of text, overlong footnotes, musical examples, and exercises. In Robert Donington's words, Buelow's partial translation of Der General Bass in der Composition (Dresden, 1728) "makes Heinichen accessible without the penalty of all those pages of difficult old German". 4

The edition of 1728 is indeed daunting; even had Buelow presented Heinichen's entire text in a clear English translation, those willing to wade through it would, I suspect, have been few in number. Heinichen surveys the figures, principles of accompanying, the problem of quick bass notes, unfigured basses, the fullvoiced style of accompaniment, the recitative (unfortunately in untexted examples), and concludes with a "practical demonstration" - a discussion of the chords appropriate for an unfigured bass from Scarlatti's cantata, "Lascia deh lascia al fine di tormentarmi più." In an appendix, Buelow gives an actual realization according to Heinichen's advice. The revised edition adds two new appendices: a complete translation of Heinichen's Introduction to the 1728 volume and a previously published discussion of Heinichen's theory of dissonance resolution. ${ }^{5}$ The additions are most welcome, especially the former for its demonstration of the utility of a rhetorical approach for composers faced with uninspiring texts. Heinichen's several musical settings, reflecting various ele-

2 It was first undertaken as a doctoral dissertation (1961), then published by the University of California Press (1966), and issued in a revised version by the University of Nebraska Press (1986).

3 See, for example, D[énis] Delair, Traité d'acompagnement pour le théorbe, et le clavessin (Paris: author, 1690), translated by Charlotte Mattax as Accompaniment on the Theorbo \& Harpsichord: Dénis Delair's Treatise of 1690 (Bloomington and Indianapolis: Indiana University Press, 1991); Monsieur de Saint Lambert, Nouveau traité de l'accompagnement du clavecin, de l'orgue, et des autres instruments (Paris: Ballard, 1707), translated by John S. Powell as A New Treatise on Accompaniment with the harpsichord, the organ, and with other instruments (Bloomington and Indianapolis: Indiana University Press, 1991); David Ledbetter, Continuo Playing According to Handel: His figured bass exercises (Oxford: Clarendon Press, 1990); and Patrick J. Rogers, Continuo Realization in Handel's Vocal Music (Ann Arbor: UMI Research Press, 1989).

4 Robert Donington, review of the 1966 edition, The Musical Times 110 (1969): 837.

5 George J. Buelow, "Heinichen's Treatment of Dissonance," Journal of Music Theory 6 (1962): 216-74. 
ments in the texts, are alone worth the price of the volume. His long footnotes, many of which present his views as a practical musician and composer impatient with conservative pedants, are not to be missed. According to one such note, "All arts and sciences have rules and must be learned through rules ... . But we must not err excessively on the side of rules .... Examine the thousands of composition rules ... and see if only very few should add the word 'always,' whereas most of them should add such words as 'generally,' 'naturally,' 'mostly,' or 'seldom", (pp. 321-22). This flexible attitude toward "rules" has some importance for the practice of figured bass accompaniment: Heinichen often notes that there is more than one option for accompanists reading from an unfigured bass (and even in the interpretation of the figures themselves), using phrases such as "more effective harmonically," "to proceed more artistically," or "for greater beauty" for the solutions he preferred and indeed expected from "more experienced accompanists."

While certainly of interest to music theorists and to all scholars concerned with baroque performance practice, Heinichen's treatise is of special importance to the growing number of keyboard players able to realize a figured bass at sight who need instruction in the conventions of accompaniment appropriate not only to particular historical times and places but also to genres of music and accompanying instruments. Now that most of us have given up the search for a universal theory of the development of musical style or even of the place of music in Western culture, we have gradually come to understand that there is no one style of figured bass realization that will serve all our musical purposes. Once we have acquired a basic competence in "keyboard harmony" (i.e., the ability to play the right chord at the right time), we must focus on individual authors and repertories if we hope to be successful in our attempts to perform baroque music in a way that its composers might recognize. Surveys and syntheses such as those of Robert Donington (The Interpretation of Early Music, 1963) and F.T. Arnold (The Art of Accompaniment from a Thorough-Bass, 1931) certainly have been important to all of us - scholars and performers alike - as introductions to what is a vast field, but they must not blind us to the fact that practices varied considerably from Monteverdi's Venice to Lully's Paris to Handel's London and varied even within those times and places in terms of genre, accompanying instrument, and individual taste. Heinichen provides just the instruction we need for the Italianate music of his time and place, and Buelow presents it in Heinichen's own terms, without inflicting the terminology of functional harmony and chord inversion.

Although Peter Williams dismissed Johann David Heinichen (1683-1729) as one of the mostly "second-rate composers" whose scores and writings offer advice on realization of figured basses, the composer and theorist in fact held an 
important post as Kapellmeister at Dresden from 1717 until his death. ${ }^{6}$ His musical training was at the Leipzig Thomasschule under Kuhnau, and he was already a successful composer of operas for Leipzig and Naumburg when he left for Italy, where he remained from 1710 until 1716. Two of his operas were successfully introduced in Venice in 1713; it was a visit to that city by the PrinceElector of Saxony in 1716 that confirmed Heinichen's appointment as Kapellmeister in Dresden, an appointment he took up early in 1717. As Buelow reminds us, Walther's (1732) biographical entry on Heinichen is more than twice as long as that given either to J.S. Bach or to Gasparini. He was an important member of the musical establishment in his time, knew intimately the musical life of Leipzig, Venice, and Dresden, and was well respected by his employers and his musical peers.

Heinichen had published the first edition of his treatise, Neu erfundene und Gründliche Anweisung ... zu vollkommener Erlernung des General-Basses (Hamburg, 1711), while still living in Venice; that volume he had substantially revised and expanded by 1728. In Italy he had known Gasparini, author of L'armonico pratico al cimbalo (1708), from which he borrowed his entire discussion of acciaccatura. But Heinichen also knew well St.Lambert's Nouveau traité de l'accompagnement of 1707; he borrowed from that source a discussion of bon goût. Throughout, Buelow compares Heinichen's views not only to these two volumes but also to David Kellner's Treulicher Unterricht im General-Bass (1732) and to Mattheson's opinions drawn from his three books for keyboard players $(1719,1731,1735)$. For both scholars and performers these comparisons are one of the most important aspects of Buelow's volume.

On the more practical side, Buelow attempts an actual realization of Heinichen's "practical demonstration" of the unfigured bass of Scarlatti's cantata. Although it is perhaps a minority opinion, I have my doubts about the usefulness of this exercise. Heinichen has already provided us with copious examples of notated realizations; whether or not these are actually, as Arnold suggested, "what he himself would have played when seated at his Harpsichord in the Opera House" (p. 257) and thus should be seen as "frozen improvisations" is far from clear. Buelow's realization does mimic closely the style of Heinichen's realized examples (usually in four voices, with chords rearticulated on nearly every beat); but does it reflect what the player would actually have produced? To my fingers, and taste, it feels awkward and not at all what I would play. Were I to rely on such a "prepared" accompaniment, I would prefer that of Arnold Schering in which

6 Peter Williams, Figured Bass Accompaniment, 2 vols. (Edinburgh: Edinburgh University Press, 1970), 1:65. 
the texture varies and chords are not repeated incessantly. ${ }^{7}$ Buelow offers us a realization of the figures, rather than an accompaniment; the distinction is not trivial although we know much more about the former than about the latter. Some surviving examples of realized basses lead one to expect a more linear and even motivic emphasis rather than the strictly chordal one fostered by the figured bass tutors, including that of Heinichen himself.

George J. Buelow has certainly produced a useful introduction to Heinichen's ideas. But scholars will still need to turn to the original since Buelow does not regularly and systematically inform us of how his version relates to Heinichen's text: we are in essence confronted with a user-friendly performing edition without a critical report. For much of the volume, one simply cannot reconstruct from the modern edition even the outline much less the details of the original. Along with reviewers of the first edition, I would rather have a complete translation or at least a translation of complete excerpts whose relation to the original is clearly indicated. ${ }^{8}$ Moreover, despite the correction of several of the errors pointed out by reviewers of the first edition, too many remain in the musical examples (e.g., p. 232 no. 23, where Heinichen needs a correction from his editor; p. 231, where no.5 is positioned one note earlier than in the source; other problems noted in passing: pp. 251 no. $10 ; 263$ no.60, 265 no. 78,267 nos.76-80). The single German reviewer of the first edition complained about the translation; although at least one of his complaints has been corrected, how many more are there? ${ }^{9}$ And Buelow, when he does translate rather than paraphrase Heinichen, does not translate the many foreign terms the author freely employed. One begins to wonder for whom the book is intended. Scholars cannot rely on it for more than an introduction because of its distance from the source; performers whose Latin is weak will be frustrated by phrases they cannot readily interpret.

With the continued flourishing of the historical performance movement, Buelow's revised edition may have today a more receptive audience - and a more important function - than it had when it first appeared in the 1960s. Even then several reviewers commented on its practical value; it is certainly true that a keyboard player willing to work his or her way through Heinichen's method will emerge fairly well equipped to play from 18th-century figured and unfigured basses in the Italianate music of the early and mid-eighteenth century. And as

7 Arnold Schering, Geschichte der Musik in Beispielen (Leipzig: Breitkopf \& Härtel, 1931), no. 260.

8 Bathia Churgin, Journal of the American Musicological Society 21 (1968): 393-96; Donald McCorkle, Music Educators Journal 56 (1970): 85-86.

9 Walter Reckziegel, Die Musikforschung 21 (1968): 381-82. 
serious players rely more and more on the original parts rather than on modern editions, Buelow's version of Heinichen will continue to be an invaluable part of their training.

Sandra Mangsen

Valerie Rumbold and Iain Fenlon, eds. A Short-Title Catalogue of Music Printed Before 1825 in the Fitzwilliam Museum, Cambridge. Cambridge: Cambridge University Press, 1992. xii, 168pp. ISBN 0-521-41535-7

This catalogue represents the "first stage" of a project to replace the century-old Fuller-Maitland and Mann Catalogue of the Music in the Fitzwilliam Museum, Cambridge (1893), long outdated by numerous additions to and deletions from the museum's collection of manuscript and printed music. The core of the collection lies in the holdings gathered by the museum's founder and namesake, Richard Fitzwilliam, seventh Viscount Fitzwilliam (1745-1816), whose life as a connoisseur and collector of seventeenth and early eighteenth century music is admirably sketched in the editors' six-page introduction.

Fitzwilliam's musical taste was influenced by his Cambridge education, to which institution he bequeathed both his collection and the funds to house them, and by his subsequent visits to France, Italy, Spain, and the Low Countries. He was interested in the so-called ancient music of the then recent past, including (quite untypically for an English gentleman of that time) French music "of the first half of the eighteenth century and before." His very particular passion was Handel, of whose published music he determined early "to build up as complete a collection as possible." Though not represented in this catalogue of printed works, he also avidly collected works in manuscript. Recorder players, for example, will know the sonatas edited by Thurston Dart from Fitzwilliam's extensive holdings of Handel manuscripts and published by Schott in 1948. The misnamed Queen Elizabeth's Virginal Book, well known as one of the most extensive and important compilations of early English keyboard music in manuscript, is also found in his collection. Indeed, Fitzwilliam's acquisition of keyboard music, published and unpublished, reflects his interest in playing keyboard instruments.

A strong supporter of early music, the Viscount encouraged and subscribed to the collected publications of Boyce, Clari, Parry, Purcell, and others. Sometimes works are inscribed to him as presentation copies from the composer or editor. Still other printed works indicate that he permitted his manuscript copies to be used as the basis for publication, although these manuscripts may not necessarily 